DOI: 10.17707/AgricultForest.64.1.19

\author{
Igor ĐUR円IĆ, Vladeta STEVOVIĆ, Vesna MILIĆ, \\ Tanja JAKIŠIĆ, Branka GOVEDARICA, \\ Milan JUGOVIĆ, Siniša BERJAN ${ }^{1}$
}

\title{
FORAGE PEA YIELD IN DIFFERENT AGROECOLOGICAL CONDITIONS
}

\begin{abstract}
SUMMARY
Since the production area of forage peas is begin to increase, the experiment was set up at two localities, Banja Luka and East Sarajevo. For experiment was used five domestic varieties Saša and NS Junior from Serbia. The experiment was carried out with three types of fertilization (without the use of mineral fertilizers, basic fertilization with NPK and basic fertilization by NPK + nitrogen addition). The variety Saša had the highest yield of green mass and hay. The application of basic fertilization had the influence on tested parameters, while the application of basic fertilizer in combination with topdressing had poorer results. Agro-ecological conditions had the influence on yield of hay, so greater results are achieved on experimental field East Sarajevo.
\end{abstract}

Keywords: forage peas, yield, hay, green mass, variety

\section{INTRODUCTION}

Peas are usually used in the diet of humans and domestic animals, but it also playing an important role in fertilization as green fertilizer. According to Eric et al. (2007), peas are cultivated in the world at 7.621.928 ha, out of which 1.046.011 ha or $13.71 \%$ is covered with forage pea. In our country pea is grown on small surfaces. Livestock peas can be used as green fodder, hay, silage, shade, for dehydration and if necessary green manure fertilizer (sideration). Pea's production is mainly focused to the production of grains, which represent concentrated animal feed. In our mountain-hilly production conditions, the production of hay is dominant, while silage production is less represented. Peas are sown mixed with cereals, mostly as early crops. Peas for the production of hay are little used, because it should be cutting in May, but May is a month with plenty of precipitation and it is difficult to dry a large mass of hay and that can affects the quality of hay which decreasing significantly. Early peas for the production of hay is cutting slightly later than the winter pea variety, when plants are in the stage of full flowering and the start of filling (Gataric et al., 2014).

\footnotetext{
${ }^{1}$ Igor Đurđić, Vesna Milić (corresponding author: vesnamlc@yahoo.co.uk), Tanja Jakišić, Branka Govedarica, Milan Jugović, Siniša Berjan, University of East Sarajevo, Faculty of Agriculture, Vuka Karadjica 30, BOSNIA AND HERZEGOVINA, Vladeta Stevović, Agronomic Faculty Čačak, University of Kragujevac, SERBIA

Notes: The authors declare that they have no conflicts of interest. Authorship Form signed online.
} 
The yield of green mass in pure crop per hectare is 25-35 t, and in the mixture with cereals up to $50 \mathrm{t} \mathrm{ha}^{-1}$ (Mišković, 1986). In the research for the production of forage (Gatarić et al., 2014), peas is fertilized with combined NPK fertilizers, with: $40-80 \mathrm{~kg}$ ha-1 nitrogen, $80-100 \mathrm{~kg} \mathrm{ha}^{-1}$ potassium and 80-120 kg $\mathrm{ha}^{-1}$ phosphorus. For the production of the early forage pea, it is recommended to fertilize with NPK (10:20:30) for lighter soil (Lončar et al., 1989, cited by Rapčan et al., 2004), and for the heavy soil with NPK (8:26:28), while Brkić (2002) recommended $40-150 \mathrm{~kg} \mathrm{ha}^{-1} \mathrm{~N}$ entering a quantity that will satisfy pea needs. For the yield of the early spring pea, amounts of rainfall in May and the first decade of June (Kovac, 1994; Rapcan et al, 2006) are very important. Since early spring pea is grown from March to July in our agroecological conditions, the negative influence of high summer temperatures occurs during the development of pods (Duthion \& Pigeaire, 1991). Temperatures above $26{ }^{\circ} \mathrm{C}$ in the stage immediately after flowering can significantly reduce the yield of grain due to decay of flowers (Popović et al., 2002).

\section{MATERIAL AND METHODS}

The experiment was set up in 2016 at the experimental field of the Agricultural Institute of Republic of Srpska in Banja Luka (altitude 160 meters) and the experimental field of the Faculty of Agriculture in East Sarajevo (altitude $550 \mathrm{~m}$ ). The field experiment was set in a randomized block design with four replications. The sowing was done at $12.5 \mathrm{~cm}$ spacing and space of $8 \mathrm{~cm}$ in the main plot of $5 \mathrm{~m}^{2}$. Seed of two varieties of fodder peas was used for sowing: NS Junior and Saša. In the study of the influence of mineral nutrition on the yield of green pea mass $\left(\mathrm{t} \mathrm{ha}^{-1}\right)$ and yield of hay $\left(\mathrm{t} \mathrm{ha}^{-1}\right)$,together with the control variant, the basic fertilizer application of $350 \mathrm{~kg} \mathrm{ha}^{-1} \mathrm{~N}_{8} \mathrm{P}_{24} \mathrm{~K}_{24}$ and a variant with basic fertilization of $350 \mathrm{~kg} \mathrm{ha}^{-1} \mathrm{~N}_{8} \mathrm{P}_{24} \mathrm{~K}_{24}+$ yield with $27 \mathrm{~kg} \mathrm{ha}^{-1}$ (27\% KAN used) were used. In Banja Luka, sowing was done on April 15 and harvest on July 15, while in East Sarajevo sowing took place on April 8, and harvest on July 18. At the floral stage, samples of the above ground mass of plants from a surface of 1 $\mathrm{m}^{2}$ were taken from each repetition. After weighing, the mass of the samples was calculated on the quantity of above ground vegetative mass in $t^{-1} a^{-1}$ Then the drying of the sample was performed to obtain an air dry weight. Than the sample was weighed and conversion was performed to obtain the yield of hay.

The obtained data were processed by the method of variance analysis (MANOVA) and tested by the LSD test (STATISTICA 7.1 for Windows (Stat Soft 2005).

\section{Agroecological conditions}

The disposition of total monthly precipitation and average monthly air temperature for 2016 and perennial average for Banja Luka and Sarajevo is shown in Table 1. The temperature conditions for pea development were favorable. Average monthly air temperatures at both sites during the testing year were more than the perennial average; only in May 2016 the mean monthly temperature was somewhat lower than the perennial average. During the 
vegetation period, precipitation oscillated from month to month. In 2016, in Banja Luka area, the extreme month was May whit only $0.5 \mathrm{~mm}$ of precipitation. Uneven precipitation patterns affect the forage pea yield.

Table 1. Average monthly air temperatures $\left({ }^{\circ} \mathrm{C}\right)$, Monthly precipitation (mm) and Perennial averages for Banja Luka and Sarajevo

\begin{tabular}{|c|c|c|c|c|c|c|c|c|c|}
\hline \multicolumn{3}{|c|}{ Month } & I & II & III & IV & V & VI & VII \\
\hline \multirow{4}{*}{ 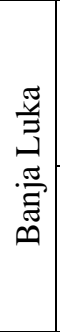 } & & $\begin{array}{l}\text { Temperature } \\
\left({ }^{\circ} \mathrm{C}\right)\end{array}$ & 2.3 & 7.6 & 8.0 & 13.5 & 16.2 & 21.5 & 23.3 \\
\hline & $\begin{array}{l}\dot{0} \\
\dot{2}\end{array}$ & $\begin{array}{l}\text { Precipitation } \\
(\mathrm{mm})\end{array}$ & 109.7 & 108.5 & 122.2 & 0.5 & 100.6 & 117.8 & 125.9 \\
\hline & \multirow{2}{*}{ 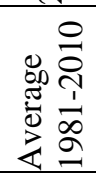 } & $\begin{array}{l}\text { Temperature } \\
\left({ }^{\circ} \mathrm{C}\right)\end{array}$ & 0.6 & 2.3 & 6.8 & 11.5 & 16.5 & 19.8 & 21.8 \\
\hline & & $\begin{array}{l}\text { Precipitation } \\
(\mathrm{mm})\end{array}$ & 69.7 & 59.1 & 87.5 & 84.3 & 89.4 & 112.4 & 81.4 \\
\hline \multirow{4}{*}{ 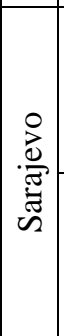 } & \multirow{4}{*}{ 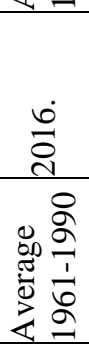 } & $\begin{array}{l}\text { Temperature } \\
\left({ }^{\circ} \mathrm{C}\right)\end{array}$ & 1.2 & 7.4 & 7.1 & 12.9 & 13.9 & 19.5 & 21.1 \\
\hline & & $\begin{array}{l}\text { Precipitation } \\
(\mathrm{mm})\end{array}$ & 46.6 & 87 & |131.7 & 60.5 & 82.1 & 96.4 & 104.5 \\
\hline & & $\begin{array}{l}\text { Temperature } \\
\left({ }^{\circ} \mathrm{C}\right)\end{array}$ & -0.8 & 1.7 & 5.5 & 10 & 14.8 & 17.7 & 19.7 \\
\hline & & $\begin{array}{l}\text { Precipitation } \\
(\mathrm{mm})\end{array}$ & 74 & 63 & 73 & 76 & 85 & 94 & 83 \\
\hline
\end{tabular}

The land on which the trials were performed in Banja Luka is of good physical characteristics with a depth of the plowed land up to $35 \mathrm{~cm}$. According to agrochemical analysis done at the Faculty of Agriculture in East Sarajevo, plowed land contains $0.13 \%$ nitrogen, 8.6\% calcium, 2.05\% humus, $4040 \mathrm{mg} /$ $100 \mathrm{~g}$ phosphorus and $38.48 \mathrm{mg} / 100 \mathrm{~g}$ potassium. The soil reaction is neutral, the $\mathrm{pH}$ in $\mathrm{nKCl}$ is 6.97, while the experiment field of the Faculty of Agriculture in East Sarajevo contains $0.27 \%$ nitrogen, $4.12 \%$ humus, $4040 \mathrm{mg} / 100 \mathrm{~g}$ phosphorus and $36.41 \mathrm{mg} / 100$ g potassium. The soil reaction is slightly acidic, the $\mathrm{pH}$ in $\mathrm{nKCl}$ is 6.39 .

\section{RESULTS AND DISCUSSION}

The average yield of green mass was $29.7 \mathrm{t} \mathrm{ha}^{-1}$ (Table 2). According to Mišković (1986) yields of green mass in pure crop per hectare is in the range 25$35 \mathrm{t}$, while in the mixture with cereals is up to $50 \mathrm{t}$. Hoffman and Dér (2003) found green mass yield of 29,68 and 33,03 t ha- in two pea genotypes, which is in accordance with our results.

The highest yield of green matter was recorded by variety Saša from Banja Luka (34,19 tha-1) and it was significantly higher compared to the other tested variety, NS Junior (25,15 t ha-1). In control variant the yield of the green mass was $24.4 \mathrm{t} \mathrm{ha}^{-1}$. In case where basic fertilization was applied, the yield was $32.3 \mathrm{t}$ $\mathrm{ha}^{-1}$, and in case of basic fertilization +addition, it was $32.4 \mathrm{t} \mathrm{ha}^{-1}$. Mineral 
fertilization had a significant influence on the yield of green matter compared to the control variant. In the variant basic fertilization + addition, yield of green mass was lover comparing to variant with only basic fertilization. The location did not have influence on the yield of green mass and it was in the ranged from $29.2 \mathrm{t} \mathrm{ha}^{-1}$ to $30.1 \mathrm{tha}^{-1}$.

Table 2. Yield of green mass $\left(\mathrm{t} \mathrm{ha}^{-1}\right) /$ for forage

\begin{tabular}{|c|c|c|c|c|}
\hline \multirow{2}{*}{ NPK quantity } & \multirow{2}{*}{ Variety } & \multicolumn{2}{|c|}{ Site } & \multirow{2}{*}{ Average } \\
\hline & & East Sarajevo & Banja Luka & \\
\hline \multirow{3}{*}{ Control } & NS Junior & 17.4 & 21.5 & 19.5 \\
\hline & Saša & 33.7 & 24.7 & 29.2 \\
\hline & Average & 25.6 & 23.1 & 24.4 \\
\hline \multirow{3}{*}{ Basic fertilization } & NS Junior & 29.7 & 27.2 & 28.5 \\
\hline & Saša & 37.0 & 35.2 & 36.1 \\
\hline & Average & 33.3 & 31.2 & 32.3 \\
\hline \multirow{3}{*}{$\begin{array}{l}\text { Basic fertilization } \\
\text { +supplementation }\end{array}$} & NS Junior & 29.6 & 25.4 & 27.5 \\
\hline & & 33.4 & 41.0 & 37.2 \\
\hline & Average & 31.5 & 33.2 & 32.4 \\
\hline \multirow{2}{*}{ Average } & NS Junior & 25.6 & 24.7 & 25.2 \\
\hline & Saša & 34.7 & 33.7 & 34.2 \\
\hline \multicolumn{2}{|l|}{ Total average } & 30.1 & 29.2 & 29.7 \\
\hline \multicolumn{2}{|l|}{ Treatments } & F-test & LSD 0,05 & LSD 0,01 \\
\hline \multicolumn{2}{|l|}{ A (variety) } & 0.002 & 5.37 & 7.22 \\
\hline \multicolumn{2}{|l|}{ B (fertilization) } & 0.027 & 6.58 & 8.84 \\
\hline \multicolumn{2}{|l|}{ C (location) } & 0.727 & 5.37 & 7.22 \\
\hline AxB (variety $x$ fert & eation) & 0.933 & 9.30 & 12.50 \\
\hline \multicolumn{2}{|c|}{ AxC (variety x location) } & 0.974 & 7.60 & 10.21 \\
\hline \multicolumn{2}{|c|}{$\begin{array}{l}\text { BxC (fertilization x location) } \\
\text { AxBxC (variety x fertilization x lcation) }\end{array}$} & 0.770 & 9.30 & 12.50 \\
\hline \multicolumn{2}{|c|}{ AxBxC (variety $\mathrm{x}$ fertilization $\mathrm{x}$ lcation) } & 0.173 & 13.16 & 17.68 \\
\hline
\end{tabular}

The average yield of hay was $7.50 \mathrm{t} \mathrm{ha}^{-1}$ (Table 3). The highest yield of hay was recorded on Sasa varieties $\left(8.61 \mathrm{t} \mathrm{ha}^{-1}\right)$, and it was significantly higher than NS Junior $\left(6.39 \mathrm{t} \mathrm{ha}^{-1}\right)$. This location had significant influence on the yield of hay and it was in the ranged from $7.75 \mathrm{t}$ ha-1 in East Sarajevo to $7.25 \mathrm{t} \mathrm{ha}^{-1}$ in Banja Luka. In the control variant, the yield of hay was $6.24 \mathrm{t} \mathrm{ha}^{-1}$. In the variant basic fertilization, the yield was $8.18 \mathrm{tha}^{-1}$, while in the variant basic fertilization + addition, was $8.09 \mathrm{t} \mathrm{ha}^{-1}$. Comparing to control variant, application of different types of fertilization, had statistically significant influence to the increase of yield of hay.

Mihailović and Mišković (1988) obtained in their experiments the hay yield of 4.7-6.7 t ha ${ }^{-1}$, while experiments of Henneberg et al. (1989) during three year trial found that hay yield depended on genotype and ranged from 1.82 to 9.80 tha $^{-1}$. Three year experiments of Tekeli and Ates (2003) showed average hay 
yields in five pea lines of 3.44-7.38 $\mathrm{t} \mathrm{ha}^{-1}$. Similar results were obtained by Ayaz et al. (2004). Our results are in accordance with the results of the quoted authors.

Table 3. Hay yield $\left(\mathrm{t} \mathrm{ha}{ }^{-1}\right) /$ for forage

\begin{tabular}{|c|c|c|c|c|}
\hline \multirow{2}{*}{ NPK quantity } & \multirow{2}{*}{ Variety } & \multicolumn{2}{|c|}{ Site } & \multirow{2}{*}{ Average } \\
\hline & & East Sarajevo & Banja Luka & \\
\hline \multirow{3}{*}{ Control } & NS Junior & 4.46 & 5.52 & 4.99 \\
\hline & Saša & 8.65 & 6.34 & 7.49 \\
\hline & Average & 6.55 & 5.93 & 6.24 \\
\hline \multirow{3}{*}{ Basic fertilization } & NS Junior & 7.62 & 6.58 & 7.10 \\
\hline & Saša & 9.49 & 9.03 & 9.26 \\
\hline & Average & 8.55 & 7.81 & 8.18 \\
\hline \multirow{3}{*}{$\begin{array}{l}\text { Basic fertilization } \\
\text { +supplementation }\end{array}$} & NS Junior & 7.59 & 6.60 & 7.09 \\
\hline & Saša & 8.68 & 9.51 & 9.09 \\
\hline & Average & 8.14 & 8.05 & 8.09 \\
\hline \multirow{2}{*}{ Average } & NS Junior & 6.56 & 6.22 & 6.39 \\
\hline & Saša & 8.94 & 8.28 & 8.61 \\
\hline \multicolumn{2}{|l|}{ Total average } & 7.75 & 7.25 & 7,50 \\
\hline \multicolumn{2}{|l|}{ Treatments } & F-test & LSD 0,05 & LSD 0,01 \\
\hline A (variety) & & $<.001$ & 0.2011 & 0.2702 \\
\hline \multicolumn{2}{|l|}{ B (fertilization) } & $<.001$ & 0.2464 & 0.3310 \\
\hline \multicolumn{2}{|c|}{$\begin{array}{l}\text { C (location) } \\
\text { AxB (variety x fertilization) }\end{array}$} & $<.001$ & 0.2011 & 0.2702 \\
\hline \multirow{2}{*}{\multicolumn{2}{|c|}{$\begin{array}{l}\text { AxB (variety x fertllization) } \\
\text { AxC (variety x location) }\end{array}$}} & 0.210 & 0.3484 & 0.4681 \\
\hline & & 0.281 & 0.2845 & 0.3822 \\
\hline \multicolumn{2}{|c|}{ BxC (fertilization x location) } & 0.032 & 0.3484 & 0.4681 \\
\hline \multicolumn{2}{|c|}{$\begin{array}{l}\text { AxBxC (variety } x \text { fertilization } x \\
\text { lcation) }\end{array}$} & 0.791 & 0.4927 & 0.6619 \\
\hline
\end{tabular}

\section{CONCLUSIONS}

Based on the obtained results, the following can be concluded:

- The highest yield of green mass had the variety Saša, while the lowest had variety NS Junior. The largest yields of hay had the varieties NS Junior and Saša, while the lowest had variety NS Junior.

-In the control variant, was recorded the smallest yields of green mass and hay. In the variant basic fertilization with NPK was recorded the best results. Thus, basic fertilization+ addition had poorer results compared to basic fertilization, in order to reduce pollution and save the environment, this measure can be omitted.

-Ecological conditions have influence on the yield of hay, while they have not affected the yield of green matter. In agro-ecological conditions in East Sarajevo, the yield of hay was significantly higher compared to the tested characteristic in the agro-ecological conditions of Banja Luka. 


\section{REFERENCES}

Ayaz S., McKenzie B.A., Hill G.D., McNeil D.L. (2004): Variability in yield of four grain legume species in a subhumid temperate environement. I. Yields and harvest index. Journal of Agricultural Science. 142: 9-19.

Brkic S. (2002): Efficiency of bacterization, fertilization of tobacco and molybdenum on the nature of the cattleman. The dissertation. Faculty of Agriculture in Osijek

Duthion C., Pigeaire A. (1991): Seed lengths corresponding to the final stage in seed abortion of three grain legumes. Crop Science 31, 1579-1583.

Erić P., Ćupina B., Mihailović V., Mikić A. (2007): One-year old fodder legumes. Scientific Institute of Field and Vegetable Crops, Novi Sad, monograph, 256 pages.

Gatarić Đ., Milanka Drinić, Radić V., Kralj A. (2014): Manufacture on oranicams and nutrition value feedin plants. Faculty of Agriculture, East Sarajevo

Henneberg R., Kolak I., Štafa Z. (1989). «Maksimirski bijeli», A new cultivator of the frozen fodder. Agronomic messenger. 1-2: 21-37.

Hoffman F., Dér F. (2003). Yield of different green forage crops, in pure stand and in mixture. Agriculturae Conspectus Scientificus. 68 (4): 275-279.

Kovac K. (1994): The effect of some intensification factors on the pea yield of intermediary type in maize-growing region (Czech). Rostlinna Vyroba 40(10), 949-956.

Mihailoviš V., Mińkoviš B. (1988). The results of the selection of grape harvesters. Proceedings of the XXII Agronomy Seminar, Neum: 320-324.

Miskovic B. (1986): Fodder herbs, IRO "Scientific Paper", Belgrade.

Popović S., Stjepanović M., Grljušić S., Čupić T., Tucak M., Bukvić G. (2002): Yield and quality of the grain of the grain pear. Fodder 44 (4), 191-197.

Rapčan Irena, Bukvić Gordana, Grljušić Sonja, Teklić Tihana, Jurišić M. (2006): The influence of agroecological cobditions and seed maturity on the grain yield and quality of field pea (Pisum sativum L.). Mljekarstvo 56 (4) 331-342.

Rapčan Irena, Jurišić M., Grljušić Sonja (2004): Reponse of pea (Pisum sativum spp. Arvense L.) at sowing term, stand and nitrogen fertilization at area of Osijek. Agronomski glasnik, 33-45.

Tekeli A.S., Ates E. (2003). Yield and its components in field pea (Pisum arvense L.) lines. Journal of Central European Agriculture. 4 (4): 313-317. 